\title{
Samardžijini pogledi na hrvatski jezik u prvoj Jugoslaviji
}

\author{
StJEPAN DAMJANOVIĆ* \\ • https://doi.org/10.31823/d.28.4.7 • \\ UDK: 811.163.42-05 Samardžija, M. • Pregledni članak \\ Primljeno: 23. studenoga 2019. • Prihvaćeno: 2. prosinca 2020.
}

Sažetak: U utorak 19. veljače 2019. godine umro je u Zaprešiću kolega i prijatelj akademik Marko Samardžija, rodom iz Vodinaca, jedan od najboljih poznavatelja povijesti hrvatskoga standardnoga jezika, a kada je riječ o najnovijoj povijesti, dakle onoj u 20. i 21. stoljeću, može se mirno reći da to razdoblje nitko nije poznavao kao on. Jedna od najboljih njegovih knjiga zove se Hrvatski jezik i pravopis od ujedinjenja do kraja Banovine Hrvatske (1918. - 1941.), objavila ju je Školska knjiga 2012. godine i u njoj se nalaze sve bitne spoznaje o tome što se s hrvatskim jezikom dogadalo u prvoj Jugoslaviji i sve one, mada po naravi jezikoslovne i filološke, imaju

* Akademik Stjepan Damjanović, prof. emeritus,

Filozofski fakultet Sveučilišta u Zagrebu, Ivana Lučića 3, 10000 Zagreb, Hrvatska, stjepan.damjanovic@ zg.ht.hr svoju kulturološku i političku vrijednost. Moj pisani tekst jest dakle pregledni rad, pokušaj da iz Samardžijine knjige izvadim i ponudim najvažnije njegove misli.

Ključne riječi: Marko Samardžija, hrvatski jezični standard, povijest hrvatskoga jezika, jezična politika u prvoj Jugoslaviji, hrvatska filologija, nasilna unifikacija jezika.

U utorak 19. veljače 2019. godine umro je u Zaprešiću kolega i prijatelj akademik Marko Samardžija, rodom iz Vođinaca, jedan od najboljih poznavatelja povijesti hrvatskoga standardnoga jezika, a kada je riječ o najnovijoj povijesti, dakle onoj u 20. i 21. stoljeću, može se mirno reći da to razdoblje nitko nije poznavao kao on. Najbolja (po mojem mišljenju) od njegovih petnaestak knjiga ${ }^{1}$ zove se Hrvatski

${ }^{1}$ Uz spomenutu knjigu za problematiku hrvatskoga jezičnoga standarda osobito su važne: Hrvatski jezik u Nezavisnoj Državi Hrvatskoj, Zagreb, 1993.; Iz triju stoljeća hrvatskoga standardnog jezika, Matica hrvatska, 
jezik i pravopis od ujedinjenja do kraja Banovine Hrvatske (1918. - 1941.), objavila ju je Školska knjiga 2012. godine i u njoj se nalaze sve bitne spoznaje o tome što se $s$ hrvatskim jezikom događalo u prvoj Jugoslaviji i sve one, mada po naravi jezikoslovne i filološke, imaju svoju kulturološku i političku vrijednost. Moj pisani tekst jest dakle pregledni rad, pokušaj da iz Samardžijine knjige izvadim i ponudim najvažnije njegove misli.

Mislim da je jedan od prikladnih načina da predstavimo ovu knjigu osvrt na svaku od triju sastavnica svakoga poglavlja. Prva sastavnica uvijek je autorova studija o problemu iz naslova. Mogli bismo reći da je to jedna prosika koja nas vodi kroz šumu problema i tekstova i koja nam pomaže da ne zalutamo. Kad ste uvodnu studiju pročitali, lakše ćete razumjeti druge dvije sastavnice. Profesor Samardžija uvijek dobro zna što prethodi razdoblju koje opisuje i što slijedi nakon njega te djelotvorno pomaže čitatelju da uoči ono bitno u procesima jezikoslovne znanosti i jezične politike. Samardžija je izričito nesklon problematičnim domišljanjima i neutemeljenim kombinacijama i to je za izgled ove knjige presudno jer i danas nerijetko živimo s problemima koji su se začeli u vremenu o kojem govori njegova knjiga.

Drugi dio jest izbor tekstova pisanih u tom vremenu. Samardžiju prije svega zanima odnos hrvatskih autora i hrvatske sredine prema hrvatskom jeziku pa su odabrani autori velikom većinom hrvatski jezikoslovci, političari i drugi javni radnici (npr. Ivan Krnic, Marijan Stojković, Blaž Jurišić, Antun Branko Šimić, Tomo Maretić, Miroslav Andrassy, Nikola Andrić, Stjepan Ivšić i brojni drugi), ali kada se ukaže potreba da se problem vidi sa srpske strane ili da se jasnije očituju srpski postupci i nastojanja, Samardžija uključuje srpske autore (npr. Dragoljub Aranđelović, Aleksandar Belić, Dušan Ivančević, Miloš Moskovljević) i tako izbjegava jednostranu sliku iz koje vidite samo polovicu teniskoga terena i samo jednoga igrača.

Upravo zbog strogoće i koherentnosti autorova postupka moguće je priloge uvrštenih jezikoslovaca i drugih pisaca danas čitati dvojako. Ako se unesete u problematiku onoga vremena, njihove tekstove možete čitati kao dramatična svjedočanstva $o$ jednom teškom vremenu i nezavidnom položaju hrvatskoga jezika u njemu, a ako te tekstove pratite kao distancirani čitatelj iz 21. stoljeća, mnogi polemični tonovi i (ne)spretne formulacije mogu Vas uveseljavati. No jedno će uočiti svaki pozorniji čitatelj: uočit će naime kako se teško probijalo prema relevantnom govoru, kako se teško napuštalo amaterske i romantične stavove. Uočit će koliko je vremena trebalo

Zagreb, 1997. Drugo, bitno prošireno, izdanje objavila je Hrvatska sveučilišna naklada 2004.; Hrvatski kao povijesni jezik, Zaprešić, 2006.; Hrvatski jezik, pravopis i jezična politika u Nezavisnoj Državi Hrvatskoj, Zagreb, 2008. 
da se počne upotrebljavati odgovarajuća terminologija ili da se npr. razlikuje književni jezik od jezične cjeline ili od govornih navika. I još nešto: koliko su ljudi kroz sva vremena impregnirani politikom, pa i onda kada načelno zastupaju mišljenje da politiku od struke treba odvojiti. Tako se često nude ideologemi umjesto znanstvenih modela.

Treći dio svakoga poglavlja jest zaglavak. Doima se kao neka popuna, kao nešto što se Samardžiji učinilo ili osobito zanimljivim ili osobito važnim u vezi s problematikom koja se u poglavlju obrađuje, nešto što nam izravno prenosi davne ugođaje i time nam pomaže da bolje razumijemo vrijeme o kojem je riječ. Tekst koji bi se kadšto mogao nazvati osoba poglavlja ili naglasak poglavlja (Rešetar, Maretićeve promjene »kroka u kretnji «, odlazak na drugi svijet Vatroslava Jagića, Radićev borongajski govor, $\gg$ Govori i piši hrvatski kako treba « - manje poznat časopis iz onoga vremena, picmokerština ili o mukama s prilagođavanjem stranih riječi, Ivan i Jovan o jeziku - šaljiva strana nastojanja da se dođe do zajedništva, preseljenje Bašćanske ploče iz Jurandvora u Zagreb, smrt Tome Maretića, Maček u genitivu, Antun Radić kao uzor u hrvatskom jeziku, hrvatski na filmu i napokon o hrvatskom jeziku kroz smijeh i suze).

I tu našu problematiku dobro je početi promatrati od studenoga 1918. godine. Dvadeset i trećega dana toga mjeseca počela je maratonska sjednica Središnjega odbora Narodnoga vijeća Slovenaca, Hrvata i Srba, a glavna je tema bila stvaranje zajedničke države u koju će ući Kraljevina Srbija i Država Slovenaca, Hrvata i Srba. Tri dana poslije, dakle 26. studenoga, izgovorio je Stjepan Radić toliko puta navođene riječi: »Ne srljajte kao guske u maglu! « No nikakve riječi i nikakvi argumenti nisu mogli pokolebati vijećnike i ugledna je delegacija stigla 28. studenoga u Beograd, dočekana je vrlo srdačno, a kako i ne bi kada je zapravo nudila Srbiji nešto što ona nikada nije imala. Dva-tri dana trajali su razgovori, da bi u ime obiju delegacija hrvatski vijećnik dr. Ante Pavelić Stariji pročitao zajedničku predstavku srpskom kralju koju je ovaj sa zadovoljstvom prihvatio i 18. prosinca Stojan Protić sastavlja prvu vladu u kojoj čak šest resora dobivaju ministri iz Hrvatske. Dva tjedna kasnije skupština Srbije potvrđuje čin ujedinjenja.

To su bili okviri novih okolnosti u kojima se našao i hrvatski jezik. Našao se on u novom političkom i komunikološkom kontekstu i stigle su ga nove i nimalo lake kušnje. Te je kušnje poticala nova jezična politika koja se naslanjala na političku postavku o jednom narodu, troplemenskom i troimenom. U stručnom smislu oslanjala se ta nova jezična politika na servis srpskih jezikoslovaca na čelu s Aleksandrom Belićem koji su kao uzor za zajednički jezični standard nudili, bolje reći nametali, 
tzv. »beogradski stil « koji je imao poslužiti kao uzor za oblikovanje državnoga jezičnoga makrostandarda. ${ }^{2}$

Na ruku su takvoj politici išli i neki rukavci jezične politike u Hrvatskoj prije ujedinjenja, prije svega pobjeda hrvatskih vukovaca u raspravama o tome kako normirati hrvatski jezik. Jedna od posljedica takve politike bila je i pojava tzv. mladih hrvatskih ekavaca, tj. onih koji su i prije ujedinjenja nasjeli na prijedlog da Hrvati trebaju napustiti »ijekavicu « ili, kako se to onda rado zvalo, »južno narječje «, a da Srbi trebaju napustiti ćirilicu. Formalno ju je potaknuo Jovan Skerlić još 1913. godine svojim tekstom Istočno ili južno narječje i dobro je imati na pameti glavne postavke toga teksta jer se vidi kako je bilo otprve jasno što Srbi hoće, ali mnogi Hrvati su se pravili da to ne vide ili doista nisu vidjeli ono što je i u tom času bilo očito. Skerlić je prognozirao brzu i sigurnu pobjedu istočnoga narječja jer njime se služi, kako je napisao, »brojem veći i kulturom jači « dio naroda, ekavica je, pisao je on, i prije i danas imala status književnoga izgovora, ona je jednostavnija i ekspresivnija, na njezinoj je strani »sila logike događanja «. I tada je i prosječno upućenom bilo jasno da je u svemu tome istina samo to da je Srba više nego Hrvata, a sve drugo jest posve upitno. Anketa koju je Skerlić organizirao uključivala je i lijep broj hrvatskih stručnjaka i književnika od kojih su nerijetki dijelom ili posve prihvaćali Skerlićevu argumentaciju, a neki su književnici, kao što smo rekli, počeli svoja djela pisati ekavski. Početak Prvoga svjetskoga rata i Skerlićeva smrt zaustavili su unekoliko taj zanos, ali uspostava nove države 1918. godine ponovno je oživjela te razgovore i povećala broj ljudi s hrvatske strane koji su prihvaćali ekavicu. Spomenut ću dio imena da ne bismo imali iluziju da je to bila kakva šačica ljudi: Ivo Andrić, Frano Alfirević, Antun Barac, Niko Bartulović, August Cesarec, Dobriša Cesarić, Ante Cetineo, Vladimir Čerina, Ulderiko Donadini, Miroslav Feldman, Josip Kosor, Vladimir Kovačić, Gustav Krklec, Miroslav Krleža, Ivan Krnic, Krunoslav Krstić, Josip Kulundžić, Jakša Kušan, Vjekoslav Majer, Milan Marijanović, Sibe Miličić,

\footnotetext{
${ }^{2}$ Čitatelj će dobro razumjeti takva raspoloženja i stavove ako pročita dva navoda. Prvi je iz teksta dr. Dragutina PROHASKE (Hrvatska njiva, I, 1917., 770-771.): »Dok bude zasebna srpska, zasebna hrvatska i slovenska literatura, dotle nema još jedinstvene jugoslavenske literature. Mora dakle da prestane živjeti srpska, hrvatska i slovenska literatura. Mora da prestane kao što je prestala da živi dalmatinska, slavonska i bosanska literatura, svaka sa svojim posebnim narječjem i pravopisom (...). Isti se proces odumiranja mora dakle da ponovi i sa srpskom, hrvatskom i slovenskom književnošću, da nastane književna Jugoslavija, jedinstvena bar po jeziku.« Komentirajući te misli, Ivan KRNIC u tekstu Jedna književnost (Hrvatska njiva, II, 1918., 2, 25-26.) piše: »Ove su reči za čudo oštre, jedre i precizne. Imaju u sebi nešto mrko i brutalno, jer osuđuju na smrt simpatije hiljadama i hiljadama vrednih i valjanih ljudi mile i svete - ali one sadržavaju u sebi poslednje ovaploćenje ideala većine naroda hrvatskoga, te su kadre potaknuti na razmišljanje, kojim bi se putom moglo doći do realizovanja ovog ideala.«
} 
Zvonko Milković3, Alija Nametak, Đuro Sudeta, Antun Branko Šimić4, Stanislav Šimić, Tin Ujević i drugi. Pristajanje uz ekavštinu opravdavano je s jedne strane ideološko-političkim razlozima, a rjeđe umjetničkima. U lipnju 1921. godine stigao je Vidovdanski ustav i zanos hrvatskih sudionika u trampi počeo je naglo nestajati, sve su dovršili hitci na Stjepana Radića u beogradskoj skupštini. Svi hrvatski književnici koji su bili na životu požurili su se ijekavizirati svoje tekstove, samo je neke pretekla smrt pa su hrvatskoj tekstologiji ostavili problem kako da se objavljuju njihova djela: klasičan je primjer poezija Antuna Branka Šimića.

Zanimljivo je međutim kako te sudionike s hrvatske strane nije previše zanimalo što se događa s drugim dijelom tobožnjega dogovora, tj. što je $s$ ćirilicom i kako se Srbi drže obećanja da će napustiti ćirilicu. A na samom početku nove države prva vlada, ona Stojana Protića, na svojoj prvoj sjednici, proglasila je ćirilicu i latinicu posve ravnopravnima na cijelom državnom teritoriju. Tom odlukom započet je dugotrajan proces koji su tadanje hrvatske novine nazvale ćirilizacija ili ćiriliziranje ili ćirilizovanje. Profesor Samardžija kaže: »Bit toga procesa nije bila u upoznavanju s ćirilicom krajeva u kojima je ona dotada bila slabije poznato ili posve nepoznato pismo, nego, kako se ubrzo pokazalo, u nametanju ćirilice i potiskivanju latinice. $\ll^{5}$ To se osobito ticalo Hrvata u Bosni i Hercegovini i u Bačkoj. Ali i u Zagrebu se na poštama počeo nuditi sve veći broj tiskanica koje su bile samo na ćirilici. ${ }^{6}$ Ta vrlo tvrda srpska politika izazivala je sve veći otpor i u Sloveniji, a posebno u Hrvatskoj.

${ }^{3}$ Kajkavac MILKOVIĆ u tekstu Za ekavštinu (Književni jug, I, 1918., 8-9, 349-350.) napisao je i ovo: »Imajući to sve na umu, a naročito da ekavština dolazi i kod Hrvata, i kod Srba, i kod Slovenaca, ne znam zašto da se mi iz severnih krajeva, koji smo kajkavci, iz čisto hrvatskog razloga ne zauzmemo za ekavštinu kao nešto nama blizo; još manje znadem zašto da se protiv ekavštine bunimo kad smo i sami ekavci govoreći 'belo' a nikada 'bijelo,' 'mleko' a nikada 'mlijeko', 'sneg' a nikada 'snijeg,' 'breg' a nikada 'brijeg' - i tako dalje redom.«

${ }^{4}$ Jedan od najvećih hrvatskih pjesnika isticao se oštrinom svojih unitarističkih stavova i prijezirom prema onim hrvatskim jezikoslovcima koji su branili hrvatsku jezičnu posebnost. Napisao je čak i rečenicu: »Za filologe imamo samo jedan pucanj u njihove filološke mozgove, i idemo dalje.« (Glas Slovenaca, Hrvata i Srba, I, 52, 1918., 2-3.). Zanimljivo je danas promatrati što se ostvarilo od predviđanja velikoga pjesnika, a što od predviđanja »dosadnih filologa «. Ta je usporedba za pjesnika vrlo porazna.

${ }^{5}$ M. SAMARDŽIJA, Hrvatski jezik i pravopis od ujedinjenja do kraja Banovine Hrvatske (1918. 1941.), Zagreb, 2012., 23.

${ }^{6}$ Dnevnik Hrvat, inače federalistički nastrojen, piše u svom uredničkom komentaru pod naslovom Ćirilica (Hrvat, 4. 10. 1925., 1): »Mi ne ćemo prihvatiti ćirilicu i kad to kažemo, ne govorimo iz mržnje prema ćirilici. Ćirilica je u prošlosti bila pismo, kojim se je služio i dobar dio Hrvata, pa je ona po tome jednako hrvatska kao i srpska. Ali mi danas ćirilicu otklanjamo s više razloga. Otklanjamo je radi toga, što po svakom nametanju i naturavanje (sic!) možemo zaključiti, da joj je s izvjesne strane namijenjena uloga da bude nositeljica velikosrpskog imperijalizma a toga ni (sic!) nećemo. Otklanjamo je radi toga što je latinsko pismo praktičnije od ćirilskoga, što je latinica svjetsko pismo a ćirilica pismo samo jednoga dijela Slavena. Ne ćemo natrag, nego naprijed ...« 
No prije no što kažemo nešto o oblicima toga otpora, moramo spomenuti još promjene u toponimiji i antroponimiji jer su te promjene također služile cilju da se osobine hrvatskoga jezičnoga standarda proglase provincijalnim osobinama i da srpski jezični standard bude prihvaćen na cijelom državnom teritoriju.

Moramo imati na pameti da su se nakon 1. prosinca 1918. godine u državnom okviru našli krajevi koji su kroz duga stoljeća bili u dodiru s različitim jezicima, u prvom redu s njemačkim, talijanskim, mađarskim i turskim, što je ostavilo znatnoga traga i na imenima mjesta i na imenima i prezimenima ljudi.

Tridesetih godina 20. stoljeća mnogo je imena mjesta promijenjeno, posebice su u Bosni mijenjani podrijetlom njemački i turski nazivi (pa je npr. Franz Josefsfeld postao Petrovo Polje, Tešanj Putnikovo Brdo, a Prnjavor Glogovac). To je vrijeme kada će i Punat postati Aleksandrovo, Gabela Stara Luka, Stražeman Požeški Trnovac, a Brod Slavonski Brod itd. No odmah su počeli i otpori mijenjanju koji su se temeljili na tvrdnji da je vrlo nezgodno i skupo mijenjati imena mjesta pa su odbili promijeniti svoje ime Mlok (u Pragovo), Vukovar (u Vukovo), Daruvar (u Podborje), Karlovac u Zrinjski Grad i sl.

Za promjenu prezimena motivi su bili brojni i različiti. Ipak, najčešće je riječ o tome da se promijene imena njemačkoga i mađarskoga podrijetla (npr. Deutsch u Dragić ili Nagy u Tomšić i sl.), dakle da se dobije politički poželjnije prezime. Drugi razlog bio je da se promijene prezimena koja su po glasovnom sastavu bila smiješna kao Sotonica, Vraškić, Bivol i sl. Akcije provedene s mnogo strasti ipak nisu donijele željenih promjena, ali neke neželjene posljedice ostale su do naših dana.

Stručno središte borbe za ujednačavanje jezika po srpskom modelu bio je beogradski časopis Naš jezik koji je uređivao Aleksandar Belić. Politika se najbolje vidi iz odnosa toga časopisa prema hrvatskim riječima. Te su riječi dobivale određene naljepnice koje su ih trebale diskvalificirati za uporabu u standardnom jeziku: jedne su proglašavane nepotrebnim provincijalizmima (pisalo se i govorilo da $\gg$ nisu poznate u celom narodu «), npr. kralježnica ili npr. posuda, druge su proglašavane »veštačkim tvorenicama «, tj. nepotrebnim kovanicama, npr. kolodvor, nogomet, sveučilište, treće su proglašavane arhaizmima, kao sol ili tko ili dapače i sl., inzistiralo se na tome da su posrijedi germanizmi (dvojba, tinta), rusizmi (točka, kist), bohemizmi (nabožan, risati, pariški), da su značenjski pogrješne (nauk, predaja, ubojica). Za riječi uobičajene u srpskom standardu nije smetalo ako su podrijetlom rusizmi ili grecizmi i sl.

Tako je časopis Naš jezik pomagao kodifikaciji državnoga jezika i jako nastojao na tome da se i pravopis ujednači i da se izradi zajednička terminologija, posebice za srednjoškolske predmete, što je u praksi značilo da se srpska terminologija pro- 
širi posvuda. Ne možemo u kratkom tekstu ni pobrojiti sva povjerenstva koja su utemeljena s tim zadatcima, a kamoli opisati njihov rad, pa ću završni dio svojega izlaganja posvetiti rastu i usustavljivanju hrvatskoga otpora takvoj politici.

Taj je otpor bio otežan i time, kao što sam već spomenuo, što su u Hrvatskoj pobijedili vukovci kojima je opisana srpska strategija bila umnogome bliska, ali su u potrazi za praktičnim rješenjima i oni bili protiv srbijanskih prijedloga i izbacili su parolu: »Beograd nam kvari jezik«, pokazujući da taj tzv. beogradski stil ne može biti temeljem zajedničkoga jezičnoga standarda. Oni predlažu drukčija rješenja, ali uvijek s mišlju o jednom jeziku i zanimljivo je da misao o jednom jeziku podupiru i oni koji stalno u svojim govorima i tekstovima pišu mi i oni, naše i vaše, tj. očito govore o dvama entitetima, o dvama objektima.

Preciznija proučavanja pokazuju kako među hrvatskim jezikoslovcima i među hrvatskim javnim radnicima uopće dolazi do promjene u smislu da u početku nastoje popraviti taj zajednički jezik, a onda se sve češće javlja misao da treba zaštititi svoje, tj. hrvatsko, što znači da se sve više probija misao da ne postoji jedan srpskohrvatski jezik, nego da treba njegovati svoj poseban hrvatski jezik. Posebno važan korak u tom se smjeru dogodio u svibnju 1936. godine kada je skupina filologa i drugih uglednih javnih radnika utemeljila Društvo Hrvatski jezik kojemu je na čelu bio Tomo Matić, a potpredsjednik Stjepan Ivšić koji će postati i glavni urednik časopisa Hrvatski jezik. U odboru su bili još Pavao Tijan, Ferdo Hefler, Franjo Fancev, Blaž Jurišić, Velimir Radonić, Marijan Stojković, Mate Ujević i Milan Strašek. Društvo i časopis Hrvatski jezik odredili su kao svrhu svojega djelovanja njegovanje hrvatskoga jezika, njegovo unaprjeđivanje, čuvanje njegova duha ... te su odredili da se to pokuša postići jačanjem zanimanja za hrvatski jezik, pisanjem članaka i knjiga te javnim predavanjima i odgovorima na pitanja javnosti koja su bivala sve češća. ${ }^{7}$ Djelatnost toga društva, zajedno s drugim događajima u državi o kojoj više nitko nije govorio sa zanosom, nego sve više s ogorčenjem, značila je jačanje svijesti i usustavljivanje znanja o hrvatskom jeziku kao posebnom jeziku koji je osobita, nezamjenjiva sastavnica hrvatske posebnosti, hrvatskoga nacionalnoga identiteta.

To prerastanje nezadovoljstva, kako kaže Marko Samardžija, u »otvoreno artikuliranje emancipacijskoga pristupa jezičnom (i pravopisnom) pitanju u Kraljevini Jugoslaviji našlo je nešto poticaja i u činjenici da su Slovenci već prije gotovo bez-

${ }^{7}$ U III. odjeljku Pravila Društva Hrvatski jezik piše: »Društvo će da postigne tu svrhu: a) nastojati da budi što veće zanimanje za rođeni jezik i njegove ljepote; b) poticati živom i pisanom riječju (izdavanjem časopisa, knjiga i t. d.) svakoga na jezičnu pravilnost, c) držati sastanke, predavanja i druge različite priredbe za postizanje postavljene svrhe, d) davati odgovore na jezična pitanja.« 
bolno izvukli svoj jezik iz 'iznadplemenskoga' makrostandarda samostalno uređujući svoj slovenski jezični standard $\ll^{8}$.

Snažno centralizirani državni ustroj Kraljevine Jugoslavije bio je ne samo skeptičan nego vrlo restriktivan spram svih posebnosti koje su nositelji te vlasti nazvali pokrajinskima i plemenskima te su jeziku u tom pogledu posvećivali osobitu pozornost. Državna uprava, pravosuđe, školstvo i vojska bili su predmet osobite brige, što je iz perspektive srpske politike značilo da hrvatskom jeziku nema pristupa u njih.

Poznata je naša narodna izreka: »Pritisnuto jače, sve to više skače.« Srpska je politika svojom bezobzirnošću izazvala mnoge u Hrvatskoj i učinila to da su se oblikovale i skupine koje više nisu bile zadovoljne ni onim što su zastupali društvo i časopis Hrvatski jezik. Kada je oblikovana Banovina Hrvatska, bilo je već jako jasno u hrvatskim kulturnim krugovima što se ne želi, ali je, kao i inače u prevratnim situacijama, manje jasno bilo kakav novi put hoćemo, koje konkretne poteze taj novi put podrazumijeva. Novo će vrijeme obilježiti jedna od najspominjanijih knjiga u povijesti hrvatskoga jezikoslovlja, ona koju su napisali Petar Guberina i Kruno Krstić, a zove se Razlike između hrvatskoga i srpskoga književnog jezika, djelo koje jako dobro pokazuje i tadašnja politička raspoloženja i sociolingvističke prilike te koje je zadobilo simboličku vrijednost unatoč uočenim slabostima. O sazrijevanju tih stavova akademik Samardžija piše:

»Svijest o postojanju razlika između srpskoga jezika (uglavnom nazivanoga (beogradskim žargonom') i hrvatskoga jezika i predodžba o veličini i naravi tih razlika oblikovale su se postupno i paralelno. Tomu su izravno pogodovali brojni izvanjezični razlozi, ponajprije unifikacijski tip direktivne jezične politike, očit praktički od početka nove države, a sustavno provođen različitim putovima (...). Premda su se protivnici takve jezične politike i na njoj oblikovane jezične prakse među tadanjim hrvatskim filolozima i intelektualcima pojavili relativno rano, ipak su se za sustavno i argumentirano suprotstavljanje takvu stanju morali stvoriti neki preduvjeti. Trebalo je ponajprije prevladati vukovsku himeru o 'čistome narodnom jeziku' kao primjeru standardnojezične pravilnosti, potom usvijestiti spoznaju da 'narodni' i književni jezik nikako nisu podudarne veličine $\mathrm{i}, \mathrm{s}$ tim $\mathrm{u}$ vezi, shvatiti i prihvatiti da ono što je pravilno u 'narodnom' jeziku ne mora biti takvo u književnom jeziku... Konačno trebalo je sve to razraditi i poduprijeti stručnim argumentima. ${ }^{9}$

\footnotetext{
${ }^{8}$ M. SAMARDŽIJA, Hrvatski jezik i pravopis od ujedinjenja do kraja Banovine Hrvatske (1918. 1941.), 23.

${ }^{9}$ Isto, 497.
} 
U Bosni i Hercegovini nije bilo visokoškolske ili kakve druge ustanove koja bi se znanstveno i stručno bavila jezičnim problemima pa su se jezične naredbe iz Beograda prihvaćale bez ikakvih značajnijih potresa i u to tiho ozračje centralistička je jezična politika lakše unosila svoje dekrete, naredbe i odluke nego što je to bilo u Hrvatskoj. U Bosni i Hercegovini nije se lako mogla nametnuti ekavica, ali je vlast $\mathrm{i}$ to pokušavala dovođenjem velikoga broja učitelja s ekavskih prostora. Iz dokumenata je posve razvidna premoć ćirilice i sve se činilo da se potisne hrvatsko gramatičko nazivlje koje je dotad u Bosni i Hercegovini bilo posve premoćno. Kontinuitet hrvatskoga jezika svojom su zavidnom razinom čuvale širokobriješka i visočka gimnazija i isusovačka gimnazija u Travniku.

Učili su nas da je povijest učiteljica života, a bilo je i onih koji su ironično dodavali da od te učiteljice nitko nikada ništa naučio nije. Hrvatskom je jezikoslovlju, i ne samo hrvatskom, trebalo jako dugo da se oslobodi adoracijskoga odnosa prema sintagmi narodni jezik jer je uporaba toga termina i onih sličnih njemu osiguravala pljesak na otvorenoj sceni unatoč činjenici da nije teško bilo razumjeti da u tzv. čistom narodnom jeziku nema složenih sintaktičkih struktura, nema termina ni za jednu znanost, ni za jednu struku, nema pravopisa ni pravogovora i mnogo toga drugoga bez čega standardni jezik ne može. Ta intelektualna nadgradnja izrasta iz društveno-političkih prilika pa je npr. pravna hrvatska terminologija bliže slovenskoj nego srpskoj, ali ako o takvim spoznajama ne vodiš računa, ideš na ruku politici kakva je bila u Kraljevini Jugoslaviji. Standardni se jezik, rekao bi profesor Samardžija, ne oblikuje »niti kome za volju niti kome za inat «, nego izrasta iz potreba određene društvene zajednice. Hrvatski pjesnik Drago Ivanišević u pjesmi Hrvatska uz ostalo kaže:

Jer Hrvatska nije zemlja, kamen, voda.

Hrvatska je riječ koju naučih od majke

i ono u riječi mnogo dublje od riječi

a pjesmu završava stihovima:

te ja kao Hrvat brat sam sviju ljudi

$i$ kud god idem sa mnom je Hrvatska!

Jasno je da pjesnik posreduje gledište da je jezik domovina, da je tako shvaćena domovina uvijek s tobom i kad nisi u Hrvatskoj, a stih »te ja kao Hrvat brat sam sviju ljudi « može poslužiti onima koji s pravom tvrde da identitetska obilježja razlikuju skupine, među njima i narode, ali ih ne suprotstavljaju. To nisu razumjeli ili nisu htjeli razumjeti oni koji su u Kraljevini Jugoslaviji vodili jezičnu i svaku drugu politiku, nisu razumjeli da jezik nije samo sredstvo sporazumijevanja, nego i identitetsko obilježje, da je on, kao što reče pjesnik i jezikoslovac Mirko Peti, »u vremenu 
sadašnjem vrijeme naše svagdašnje «, da je on prenositelj i čuvar kulturnih vrijednosti svakoga naroda. Stoga su pristaše i zagovornici unifikacije unatoč tomu što se činilo mnogima, a ne samo Skerliću, da će pobjeda unifikacije biti brza i laka, bitku izgubili jer su se sreli s otporom koji je što svjesno, a što nesvjesno računao $s$ onim u riječi mnogo dubljim od riječi i koji se borio za svoje prirodno pravo da svojim jezikom izražava svoje civilizacijske potrebe i da svojim jezikom čuva kulturne vrijednosti koje je namro svojim budućim naraštajima. 


\title{
SAMARDŽIJA'S VIEWS ON THE CROATIAN LANGUAGE IN THE FIRST YUGOSLAVIA
}

\author{
Stjepan DAMJANOVIĆ*
}

Summary: My esteemed colleague and friend, academician Marko Samardžija, F.C.A., died on Tuesday, 19 February 2019, in Zaprešić. He was born in Vodinci. He was one of the leading authorities on the history of the Croatian standard language, and when it comes to modern history of the $20^{\text {th }}$ and the $21^{\text {st }}$ century, we can safely say that his expertise was unparalleled. Among the fifteen books that he wrote, one of the best is Croatian language and spelling: from unification to the end of Croatian Banovina (1918-1941), published by Školska knjiga in 2012. It contains all significant insights regarding the developments of the Croatian language during the period of the first Yugoslavia, which, albeit linguistic and philological by nature, still have their cultural and political value. My written paper is, therefore, a review, an attempt to excerpt and submit the most relevant thoughts from Samardžija's book.

Keywords: Marko Samardžija, Croatian standard language, history of Croatian language, language policy in the first Yugoslavia, Croatian philology, violent unification of languages.

* Academician Stjepan Damjanović, professor emeritus, Faculty of Humanities and Social Sciences, University of Zagreb, Ivana Lučića 3, 10000 Zagreb, Croatia, stjepan.damjanovic@zg.ht.hr 